American Journal of Environmental Sciences 8 (1): 64-70, 2012

ISSN 1553-345X

(C) 2012 Science Publications

\title{
Biofilter Treating Ammonia Gas Using Agricultural Residues Media
}

\author{
Thaniya Kaosol and Nutthawut Pongpat \\ Department of Civil Engineering, \\ Faculty of Engineering, Environmental Engineering Program, \\ Prince of Songkla University, Songkhla, 90110, Thailand
}

\begin{abstract}
Problem statement: Agricultural residues such as manure and sugarcane bagasse are wastes from agro-industry which has low value and requires some sustainable waste management method. In this research, a mixture of manure fertilizer and sugarcane bagasse is used as a biofilter media for an ammonia gas removal application. The aim of this research is to study the ammonia gas removal efficiency of such media. Approach: The experiments were conducted in laboratory-scale biofilters. Two inlet ammonia gas concentrations were used which are 500 and 1,000 ppm. Three ratios of manure fertilizer and sugarcane bagasse were studied including 1:3, 1:5 and 1:7 by volume. All experiments were conducted for a period of 40 days. Two Empty Bed Retention Time (EBRT) of these experiments were used which is $39 \mathrm{~s}$ and $78 \mathrm{~s}$. The moisture content of the biofilter media was maintained at $45-60 \%$ by adding water. Results: The maximum ammonia gas removal efficiency at 89.93\% is observed from the following conditions: $500 \mathrm{ppm}$ of the inlet ammonia gas concentration, the manure fertilizer and sugarcane bagasse mixture ratio of 1:5 and the EBRT of 78s. The important factors of the ammonia gas removal in biofiltration process are the inlet ammonia gas concentration and the EBRT. Conclusion: The experimental results showed that the mixture of manure fertilizer and sugarcane bagasse is an effective biofilter media for ammonia gas removal applications. However, the biofilter is more effective at low inlet ammonia gas concentration, while the ratio of manure fertilizer and sugarcane bagasse has no significant effect on the ammonia gas removal efficiency. Therefore, using both residues as biofilter media for ammonia gas removal application is an alternative sustainable way to such manage argo-industry waste.
\end{abstract}

Key words: Biofiltration, biofilter media, elimination capacity, ammonia gas

\section{INTRODUCTION}

Ammonia gas is a colorless, odorous, corrosive and toxic gas. It is produced from several sources such as composting and fertilizer plant (Busca and Pistarino, 2003), wastewater treatment plants, livestock farming (Chung et al., 1996; Ndegwa et al., 2008) and the chemical and manufacturing industries (Kim et al., 2007). There are many technologies for ammonia removal such as the catalytic oxidation (Juutilainen et al., 2006; Wang et al., 1999), liquid absorption (Chen, 2004; Terasaka et al., 2002), solid adsorption (Rodrigues et al., 2007; Guo et al., 2005) and biological filtration (Smet et al., 2000; Hong and Park, 2005; Pagans et al., 2005; Chung et al., 2005; Kim et al., 2000).

The biological treatment is an emerging technology for treating odorous air pollution. The biofiltration is one of several biological treatment methods. The biofiltration is an ammonia gas pollution control method using living materials to capture and biodegrade pollutants. Biofiltration is the most attractive alternative method for ammonia gas treating because its high removal efficiency, low operation and maintenance cost and modest environmental impact (Wani et al., 1997). In the biofiltration process, a contaminated gas stream passes through a biofilter media layer such as compost, soil, wood chips, peat, mulch, bark or mixed materials. These layers will help adsorbed the ammonia gas in the stream. After that a biodegradation occurs due to the microorganisms activity in the biofiler followed by biodegradation of adsorbed pollutants (Pagans et al., 2007). The biofilter media uses the microorganisms to remove the air pollution. Moreover the biofiltration is a proven technology as an odor and volatile organic compound reducing emission method from industrial and commercial emission sources (Taghipour et al., 2008).

Corresponding Author: Thaniya Kaosol, Department of Civil Engineering, Environmental Engineering Program,

Faculty of Engineering, Prince of Songkla University, Songkhla, 90110, Thailand 
A good biofilter media should have rich nutrients for microorganisms. Thus, manure fertilizer has sufficient nutrient as required. However, the dense and packed volume characteristics of manure fertilizer may not allow gas to pass through easily. Therefore, another media such as sugarcane bagasse that can increase void space in the manure fertilizer must be added. Sugarcane bagasse is an agro-industry waste from sugarcane industry. By using sugarcane bagasse as a biofilter media, the waste can be reduced and managed in a sustainable way. However, a study on how to mix both materials to get the highest efficiency must be conducted.

In this study, the ammonia gas removal is evaluated by a laboratory-scale biofilter using a mixture of manure fertilizer and bagasses as the biofilter media. The ammonia gas, before and after biofiltration were analyzed to determine the effect of the biofilter on the removal efficiency.

\section{MATERIALS AND METHODS}

Raw materials: The manure fertilizer and sugarcane bagasses are used as the agricultural residue biofilter media in these experiments (Fig. 1). The manure fertilizer is a product from animal waste composting which has the advantage of adding a balanced set of nutrients to soil. It contains many nutrients for microorganisms such as nitrogen, phosphorus, potassium, trace nutrients and soil microorganism stimulants.

The typical sugarcane bagasse is a fibrous matter that remaining from the juice extraction from the sugarcane stalk. The moisture content is high in range 40-50\%. The typical sugarcane bagasse contains 45$55 \%$ of cellulose, $20-25 \%$ of hemicelluloses, $18-24 \%$ of lignin, $1-4 \%$ of ash and less than $1 \%$ of waxes.

Experimental setup: The diagram of the biofiltration process used is shown in Fig. 2. In this study, three biofilter reactors were used; each reactor consists of a cylindrical vessel. The biofilter column height is 100 $\mathrm{cm}$. The biofilter column has an inner diameter of 0.10 $\mathrm{m}$. The filter bed has two layers and each layer has a height of 0.25 and $0.50 \mathrm{~m}$. The overall volume of the filter bed is 1.961 and 3.931 . The gas feeding apparatus is set up to produce an ammonia gas with desired concentration and flow rate. A peristaltic pump is used to send water from a water tank to filter bed. The manure fertilizer and sugarcane bagasse $(2 \times 2 \mathrm{~cm}$ in weight $\times$ length) were packed into the filter bed at 1:3, 1:5 and 1:7 of manure fertilizer and sugarcane bagasse ratio. The sugarcane bagasses were proved to be very effective in preventing bed compaction of organic packing media.
The reactor has the biofilter media as manure fertilizer combined with sugarcane bagasse at 1:3, 1:5 and 1:7 ratios for reactor 1,2 and 3, respectively. The biofilter media height is set as at a constant height of 0.25 and $0.50 \mathrm{~m}$. Table 1 shows the operating conditions of the biofilter in this study. The inlet ammonia gas flow rate was maintained at $50 \mathrm{~cm}^{3} \mathrm{sec}^{-1}$. The moisture content of the biofilter media was maintained at $45-60 \%$ for optimum operation condition. The Empty Bed Retention Time (EBRT) was 39s and $78 \mathrm{~s}$. The experiments were started at $500 \mathrm{ppm}$ of inlet ammonia gas concentration.

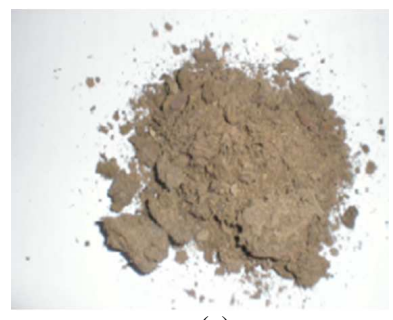

(a)

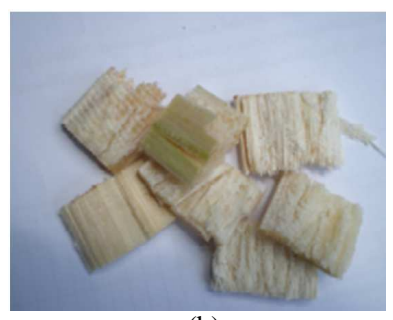

(b)
Fig. 1:Biofilter media (a) manure fertilizer (b) sugarcane bagasse

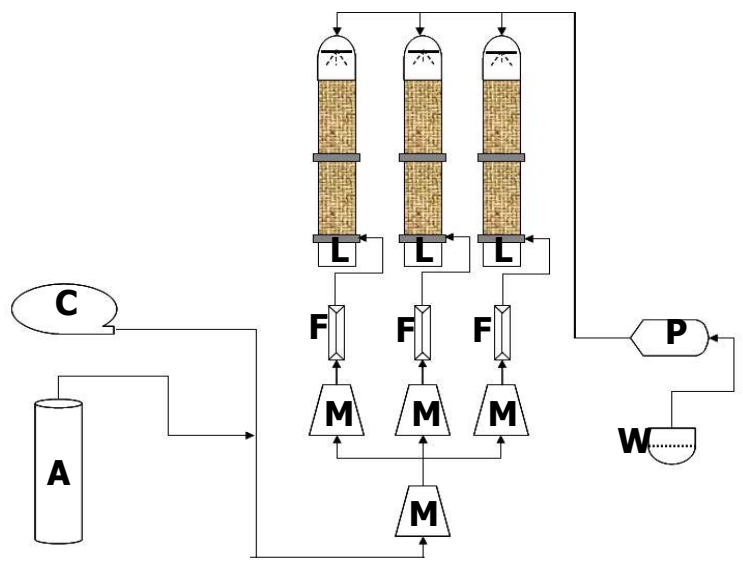

Fig. 2: Schematic of biofiltration process $\left(\mathrm{A}=\mathrm{NH}_{3}\right.$ gas tank, $\mathrm{C}=$ compressed air equipment, $\mathrm{F}=$ flow meter, $\mathrm{L}=$ leachate tank, $\mathrm{M}=$ mixed air and $\mathrm{NH}_{3}$ gas tank, $\mathrm{P}=$ peristaltic pump, and $\mathrm{W}=$ water tank)

Table 1: Operating conditions of the biofilters

\begin{tabular}{ll}
\hline Parameters & Experimental operation \\
\hline 1. $\mathrm{NH}_{3}$ flowrate & $50 \mathrm{~cm}^{3} \mathrm{~s}^{-1}$ \\
2. inlet $\mathrm{NH}_{3}$ concentration & $500 \mathrm{ppm}$ and $1,000 \mathrm{ppm}$ \\
3. Moisture content of biofilter media & $45-60 \%$ \\
4. EBRT & $39 \mathrm{~s}$ and $78 \mathrm{~s}$ \\
5. Height of biofilter media & $0.50 \mathrm{~m}$ and $0.25 \mathrm{~m}$ \\
6. Manure fertilizer: & $1: 3,1: 5$ and $1: 7$ \\
$\quad$ Sugarcane bagasse ratio & \\
7. $\mathrm{pH}$ & $6-8$ \\
\hline
\end{tabular}


The experiments were carried out continuously until the biofiltration process reached the steady state then the experiments were changed to $1,000 \mathrm{ppm}$ of inlet ammonia gas concentration.

The experiments were carried out continuously until the biofilter got into another steady state. Then the experiments finished. The $\mathrm{pH}$ value during experiments was maintained in a range between 6 and 8 .

Monitoring parameters: During the experimental period, the inlet and outlet ammonia gas concentration of each reactor were monitored to evaluate the ammonia gas removal capacity of the biofilter. The ammonia gas was collected using the sampling pump for $1 \mathrm{~min}$ at the flow rate $21 \mathrm{~min}$. Then, the passing ammonia gas is directed to the Erlenmeyer flask containing $50 \mathrm{~mL}^{-1}$ of boric acid. After that the $0.02 \mathrm{~N}$ Hydrochloric acid is used to titrate the sample in order to analyze the ammonia gas concentration.

\section{RESULTS}

Biofilter media characteristics: The properties of biofilter media, manure fertilizer and sugarcane bagasse, are shown in Table 2. The moisture content of manure fertilizer and sugarcane bagasse were $2.7 \%$ and $9.1 \%$, respectively. The moisture content is a major parameter for the operation control of the biofiltration process. The optimum moisture content of a biofilter media should be 40-60\% (Gaudin et al., 2008). Thus, water must be added to the biofilter media in order to maintain the moisture content within the optimal range.

The $\mathrm{pH}$ is 8.6 and 5.1 for manure fertilizer and sugarcane bagasse, respectively. The bulk density is 0.23 and $0.16 \mathrm{~g} \mathrm{~m}^{-3}$ for manure fertilizer and sugarcane bagasse, respectively. The nutrient elements in N: P: K form of manure fertilizer and sugarcane bagasse are 2.37: 0.78: 0.91 and 0.20: 0.03: 0.42, respectively. These nutrient elements are suitable for microorganism activity in the biofiltration process.

The $\mathrm{C} / \mathrm{N}$ ratio of manure fertilizer and sugarcane bagasse is 5.5 and 120 , respectively. The organic carbon of manure fertilizer and sugarcane bagasses is $13.1 \%$ and $24.0 \%$ dry weight, respectively. The organic matter of manure fertilizer and sugarcane bagasse is $22.7 \%$ and $41.4 \%$ dry weight, respectively.

Overall biofilter performance: The experiments were conducted for a period of 40 days. Figure 3-5 show the relationship between the inlet and outlet ammonia gas concentration and the ammonia gas removal efficiency at EBRT 39s and $78 \mathrm{~s}$ at $1: 3,1: 5$ and $1: 7$ of manure fertilizer and sugarcane bagasse ratio.

The removal effeciency of the whole 40-day period is plotted in Fig. 6-8. Figure 6 shows the RE at EBRT 39s of all three ratios of manure fertilizer and sugarcane bagasse, while Fig. 7 shows the RE at EBRT 78s of all three ratios as well. Figure 8, on the other hand, combines the plots of both figures (EBRT 39s and EBRT 78s) for comparison purpose.

Table 2: Properties of biofilter media

\begin{tabular}{llcr}
\hline Properties & Unit & $\begin{array}{l}\text { Manure } \\
\text { Fertilizer }\end{array}$ & $\begin{array}{l}\text { Sugarcane } \\
\text { bagasse }\end{array}$ \\
\hline 1. Moisture content & $\%$ & 2.70 & 9.10 \\
2. pH & - & 8.60 & 5.10 \\
3. Bulk density & $\mathrm{g} \mathrm{m}^{-3}$ & 0.23 & 0.16 \\
4. C/N ratio & - & 5.50 & 120.00 \\
5. Organic carbon & $\%$ dry weight & 13.10 & 24.00 \\
6. Organic matter & $\%$ dry weight & 22.70 & 41.40 \\
7. Nutrient elements & & & \\
- N & $\%$ & 2.37 & 0.20 \\
- P & $\%$ & 0.78 & 0.03 \\
- K & $\%$ & 0.91 & 0.42 \\
\hline
\end{tabular}

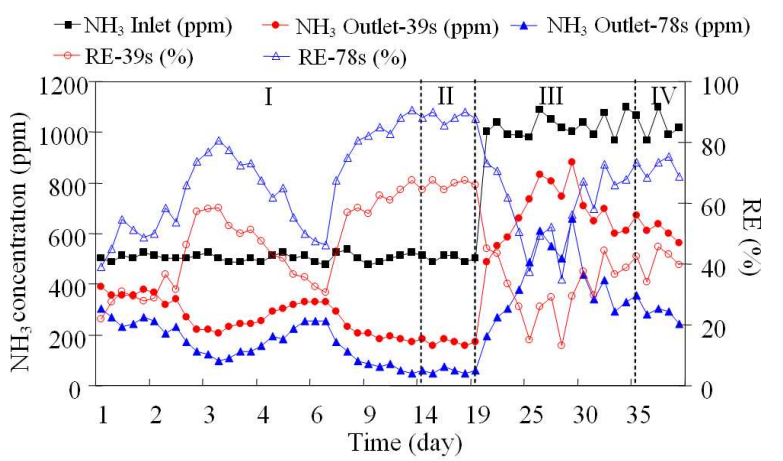

Fig. 3:Relationship between inlet ammonia gas, outlet ammonia gas and removal efficiency at 1:3 of manure fertilizer: sugarcane bagasse ratio

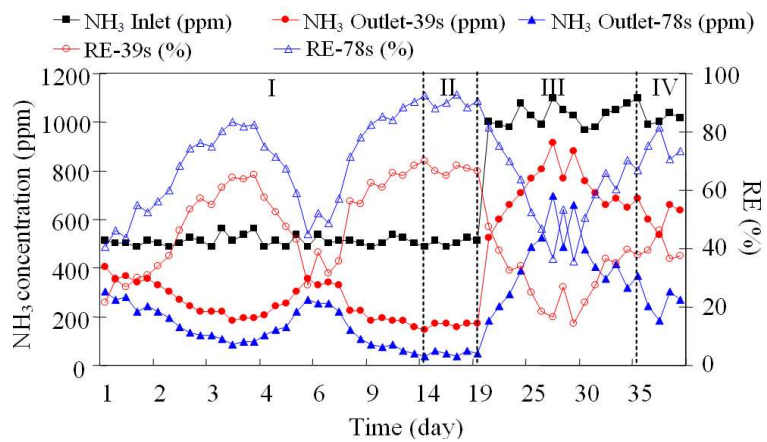

Fig. 4: Relationship between inlet ammonia gas, outlet ammonia gas and removal efficiency at 1:5 of manure fertilizer: sugarcane bagasse ratio 


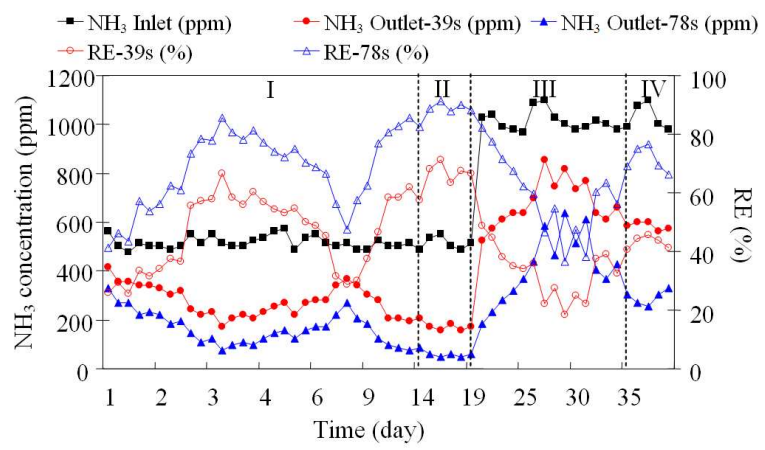

Fig. 5: Relationship between inlet ammonia gas, outlet ammonia gas and removal efficiency at 1:7 of manure fertilizer: sugarcane bagasse ratio

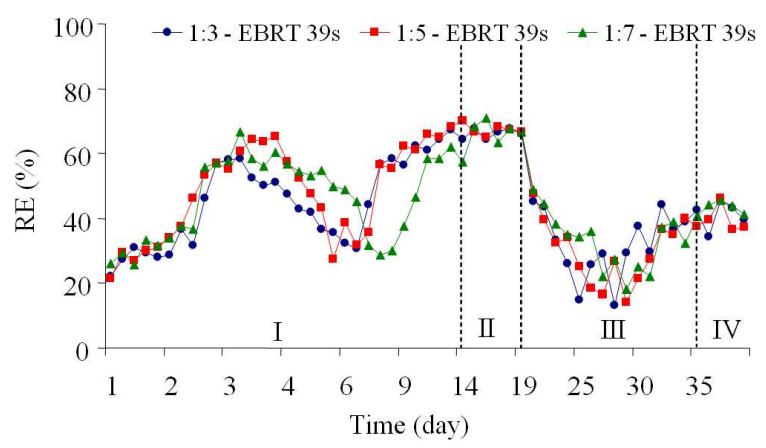

Fig. 6:Ammonia gas removal at EBRT 39s at various biofilter media ratios

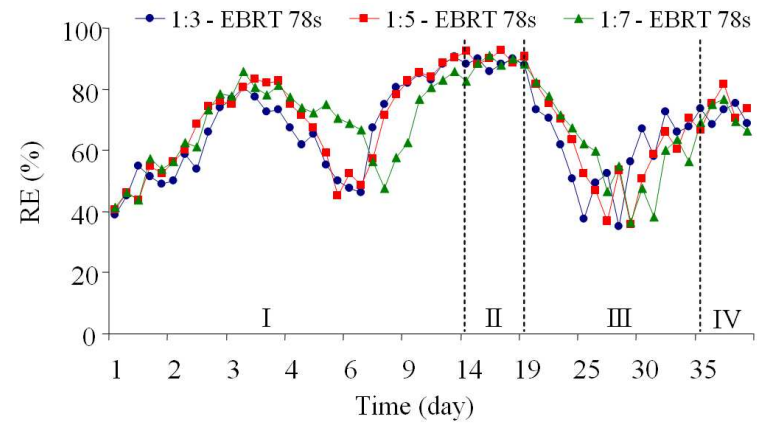

Fig. 7: Ammonia gas removal at EBRT 78s at various biofilter media ratios

The properties of the biofiltration process are shown in Table 3, including the ratio of manure fertilizer and sugarcane bagasse, inlet ammonia concentation, EBRT, mass loading, RE and Elimination Capacity (EC). Furthermore, the relationship of mass loading, RE and EC versus all three ratios of manure fertilizer and sugarcane bagasse as biofilter media are shown in Fig. 9-11, respectively.

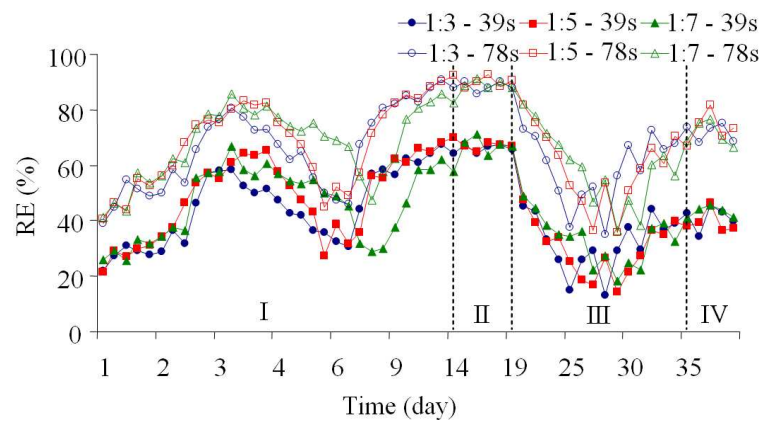

Fig. 8: Ammonia gas removal at EBRT $39 \mathrm{~s}$ and $78 \mathrm{~s}$ at various biofilter media ratios

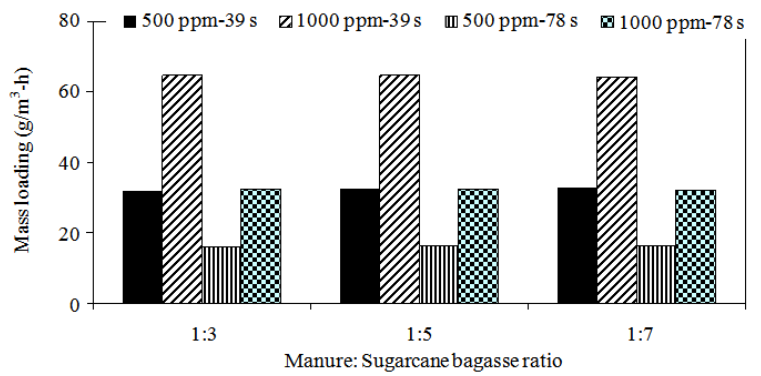

Fig. 9: Mass loading of biofiltration process at various biofilter media ratio

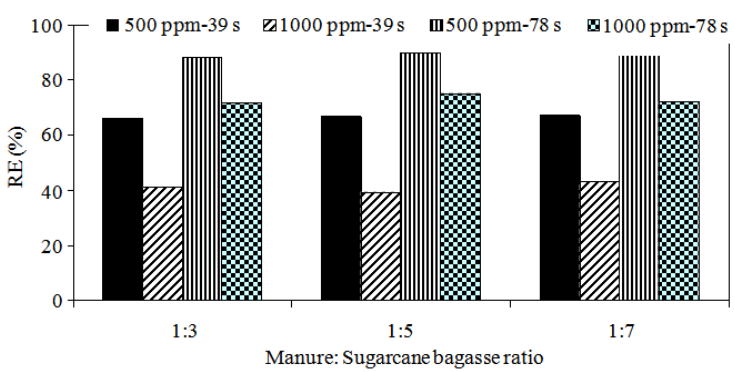

Fig. 10: Removal Efficiency (RE) of biofiltration process at various biofilter media ratio

Table 3: Properties of biofiltration process

\begin{tabular}{lcllll}
$\begin{array}{l}\text { Manure fertilizer } \\
\text { sugarcane } \\
\text { bagasse ratio }\end{array}$ & $\begin{array}{l}\text { Inlet } \\
\mathrm{NH}_{3} \text { conc. } \\
(\mathrm{ppm})\end{array}$ & $\begin{array}{l}\text { EBRT } \\
(\mathrm{s})\end{array}$ & $\begin{array}{l}\text { Mass } \\
\text { loading } \\
\left(\mathrm{g} \mathrm{m}^{-3} \mathrm{~h}^{-1}\right)\end{array}$ & $\begin{array}{l}\mathrm{RE} \\
(\%)\end{array}$ & $\begin{array}{c}\mathrm{EC} \\
\left(\mathrm{g} \mathrm{m}^{-3} \mathrm{~h}^{-1}\right)\end{array}$ \\
\hline $1: 3$ & 500 & 39 & 31.89 & 66.36 & 21.01 \\
& & 78 & 15.94 & 88.32 & 13.98 \\
& 1,000 & 39 & 64.58 & 41.05 & 26.73 \\
$1: 5$ & & 78 & 32.29 & 71.86 & 23.33 \\
& 500 & 39 & 32.27 & 66.81 & 21.48 \\
& & 78 & 16.14 & 89.93 & 14.45 \\
$1: 7$ & 1,000 & 39 & 64.70 & 39.43 & 25.03 \\
& & 78 & 32.35 & 75.24 & 23.88 \\
& 500 & 39 & 32.62 & 67.37 & 22.09 \\
& & 78 & 16.31 & 89.13 & 14.60 \\
& 1,000 & 39 & 64.20 & 43.40 & 28.27 \\
& & 78 & 32.10 & 72.05 & 23.48 \\
\hline
\end{tabular}




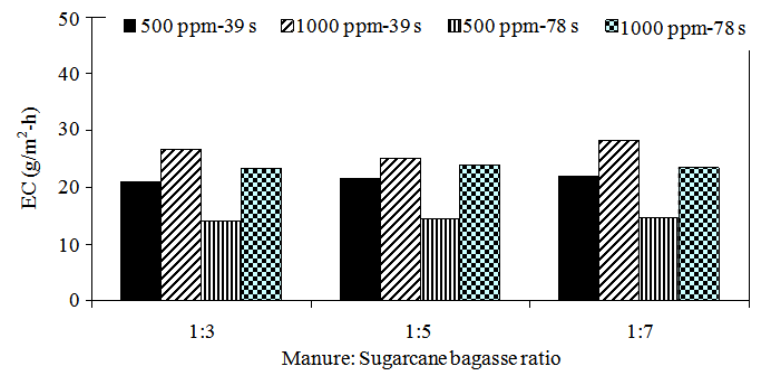

Fig. 11:Elimination Capacity (EC) of biofiltration process at various biofilter media ratio

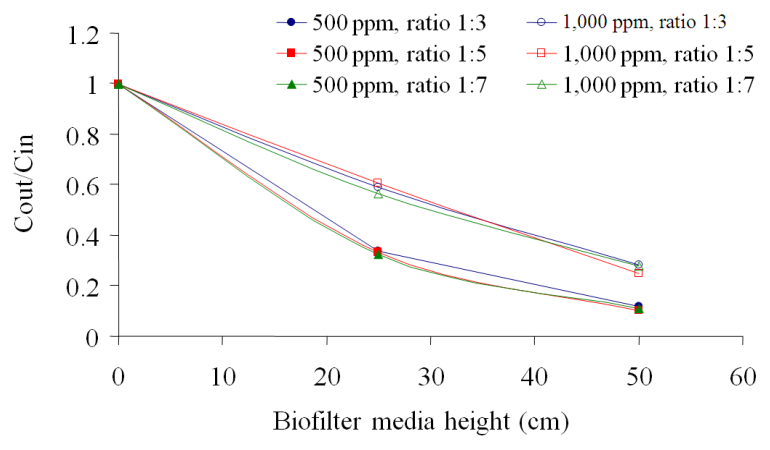

Fig. 12: Relation between biofilter media height and Cout/Cin at various biofilter media ratios

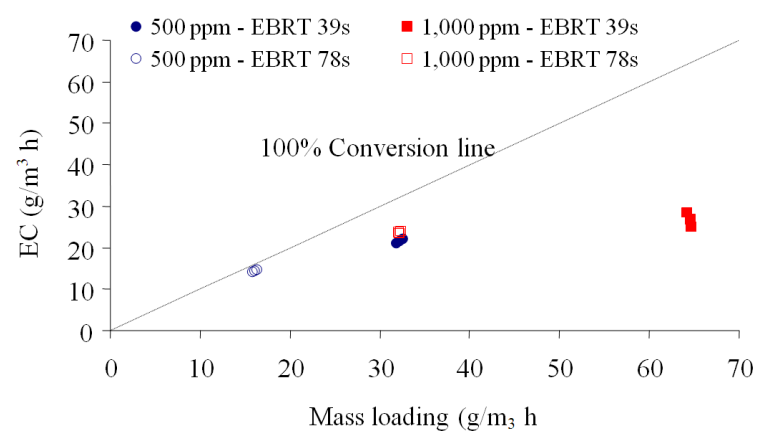

Fig. 13:Relation between mass loading and elimination capacity using manure fertilizer and sugarcane bagasse as biofilter media at various ammonia concentrations

The relationship of biofilter media height versus the outlet concentration and inlet concentration ratio at various biofilter media ratios during the whole experimental period is shown in Fig. 12.

The relationship of EC versus mass loading at various ammonia concentrations and various EBRT values during the whole experimental period is shown in Fig. 13.

\section{DISCUSSION}

The overall performance of all three biofilter media ratios (i.e., 1:3, 1:5 and 1:7) of manure fertilizer and sugarcane bagasse shows the similar trends (Fig. 3-5). The ammonia Removal Efficiencies (RE) were 66.36$67.37 \%$ at $500 \mathrm{ppm}$ of inlet ammonia air concentration and the EBRT 39s. While RE were $88.32-89.93 \%$ at $500 \mathrm{ppm}$ of inlet ammonia air concentration and the EBRT 78s. RE were $39.43-43.40 \%$ at $1,000 \mathrm{ppm}$ of inlet ammonia air concentration and the EBRT 39s. RE were $71.86-75.24 \%$ at $1,000 \mathrm{ppm}$ of inlet ammonia air concentration and the EBRT 78s.

The results revealed that the ammonia air removal is more efficient at $500 \mathrm{ppm}$ of inlet ammonia air concentration when comparing with the efficiency at $1,000 \mathrm{ppm}$ of inlet ammonia air concentration. The ammonia air removal efficiency at the EBRT $78 \mathrm{~s}$ is better than that at the EBRT 39s.

The experimental operation can be divided into four periods (I, II, III, IV) according to the inlet ammonia gas concentration and the steady state of the ammonia gas removal (Fig. 6-8). In phase I, the biofiltration process starts at the lowest inlet ammonia gas concentration $(500 \mathrm{ppm})$. The biofiltration process run until the biofiltration process achieves the steady state (phase II). After that the inlet ammonia gas is changed to $1,000 \mathrm{ppm}$ (phase III). The biofiltration process operates until the biofiltration process is steady (phase IV). The biofiltration experiment period was 40 days. The RE results at each EBRT value (39s and 78s) Fig. 6 and 7 show similar trend.

The results show that the biofilter media ratio is not a significant factor in the ammonia gas removal process. The inlet ammonia gas concentration is the main factor influencing the biofiltration operation. The highest removal efficiency is found at $500 \mathrm{ppm}$ of inlet ammonia gas concentration.

The ammonia gas removal efficiency comparison of the EBRT 39s and 78s showed that the ammonia gas removal efficiency at EBRT of $78 \mathrm{~s}$ is better than that at EBRT of 39s at the various ratios of manure fertilizer and sugarcane bagasse in biofilter media were 1:3, 1:5 and 1:7. All of manure fertilizer and sugarcane bagasse ratios in Fig. 8 showed that the ammonia gas removal efficiency was found to be similar. In conclusion, the EBRT has a significant impact on the ammonia gas removal efficiency while the ratio of manure fertilizer and sugarcane bagasse has no significant impact.

The properties of the biofiltration process are shown in Table 3. The highest performance observed in this study at the EBRT $78 \mathrm{~s}$ and $500 \mathrm{ppm}$ of inlet ammonia gas concentration, with the ammonia gas Elimination Capacity (EC) of 13.98, 14.45 and 14.60 
$\mathrm{g} \mathrm{m}^{-3} \mathrm{~h}^{-1}$ and the ammonia gas Removal Efficiency (RE) of $88.32 \%, 89.93 \%$ and $89.13 \%$ at $1: 3,1: 5$ and $1: 7$ of manure fertilizer and sugarcane bagasse ratios, respectively. While the lowest performance observed in this study at the EBRT 39s and 1,000 ppm of inlet ammonia gas concentration with the EC of 26.73, 25.03 and $28.27 \mathrm{~g} \mathrm{~m}^{-3} \mathrm{~h}^{-1}$ and the RE of $41.05 \%, 39.43 \%$ and $43.40 \%$ at $1: 3,1: 5$ and $1: 7$ of manure fertilizer and sugarcane bagasse ratios, respectively (Fig. 9-10). The results indicated that the manure fertilizer and sugarcane bagasse ratio of biofilter media was not a significant influence factor for ammonia gas removal efficiency in the biofiltration operation process. The maximum EC of ammonia gas is $28.27 \mathrm{~g} \mathrm{~m}^{-3} \mathrm{~h}^{-1}$ at the EBRT of $39 \mathrm{~s}$, the manure fertilizer and sugarcane bagasse ratio of 1:7 and the inlet ammonia gas concentration of $1,000 \mathrm{ppm}$.

The result in Fig. 9 shows the inlet ammonia gas concentration increases and the mass loading also increases in all experiments. At the same inlet ammonia gas concentration level, the ammonia gas Removal Efficiency (RE) is tended toward the same result. The result can be indicated that the ratio of manure fertilizer and sugarcane bagasse as a biofilter media has no significant impact on the value of ammonia gas removal efficiency (Fig. 10). The result in Fig. 10 showed that the inlet ammonia gas concentration in the biofiltration process improved the EC of ammonia gas. The results also imply that the manure fertilizer and sugarcane bagasse ratio in biofilter media has no significant impact on the EC of ammonia gas at both the inlet ammonia gas concentration $500 \mathrm{ppm}$ and 1,000 ppm. However, the EBRT has significant influent on the EC of ammonia gas. In addition, the EC of biofiltration at EBRT 78s is lower than that at EBRT 39s (Fig. 11).

The result in Fig. 12 showed that increasing of the biofilter media height provides the low outlet ammonia gas concentration and the low inlet ammonia gas concentration ratio (Cout/Cin ratio). The lowest Cout/Cin ratio at $500 \mathrm{ppm}$ and $1,000 \mathrm{ppm}$ is observed at $50 \mathrm{~cm}$ of biofilter media height. The result in Fig. 13 shows all mixtures of manure fertilizer and sugarcane bagasse ratios at $500 \mathrm{ppm}$ of inlet ammonia gas concentration for EBRT 39s and $78 \mathrm{~s}$ and at $1,000 \mathrm{ppm}$ of inlet ammonia gas concentration for EBRT 78s, converse according to the theory. The EC value from the mass loading value is very close to the $100 \%$ conversion line. Except at $1,000 \mathrm{ppm}$ of inlet ammonia gas concentration at EBRT 39s, the elimination capacity value from the mass loading value is not close to the $100 \%$ conversion line. Thus, the ammonia gas removal using manure fertilizer and sugarcane bagasse as the biofilter media in biofiltration process is quite effective at low inlet ammonia gas concentration and high EBRT value.

\section{CONCLUSION}

The experimental results demonstrated that the ammonia gas was successfully eliminated in a laboratory scale biofiltration process using manure fertilizer and sugarcane bagasse as biofilter media in this study. The EC increases when the inlet ammonia gas concentration increases. The low inlet ammonia gas concentration results in a higher or more effective in biofiltration process than the high inlet ammonia gas concentration. However, the high EBRT provides the good ammonia gas removal efficiency. The manure fertilizer and sugarcane bagasse ratio (i.e., 1:3, 1:5 and 1:7) has no significant impact on the ammonia gas removal efficiency in this study. The maximum ammonia gas removal efficiency is $89.93 \%$ at $1: 5$ ratio of manure fertilizer: sugarcane bagasse ratio for biofiltration process.

The experiments can concluded that the manure fertilizer and sugarcane bagasse are suitable biofilter media for a biofiltration process. The mixture ratio between manure fertilizer and sugarcane bagasse has no significant effect on the ammonia gas removal efficiency. The influence factors of ammonia gas removal efficiency in biofiltration process are the degree of inlet ammonia gas concentration and the EBRT.

\section{ACKNOWLEDGEMENT}

This study was financial supported by a grant from Prince of Songkla University, Thailand (Project ENG520250s).

\section{REFERENCES}

Busca, G. and C. Pistarino, 2003. Abatement of ammonia and amines from waste gases: A summary. J. Loss Prevention Process Ind., 16: 157163. DOI: $10.1016 / \mathrm{S} 0950-4230(02) 00093-1$

Chen, W.H. 2004. Atmospheric ammonia scavenging mechanisms around a liquid droplet in convective flow. Atmos. Environ., 38: 1107-1116. DOI: 10.1016/j.atmosenv.2003.11.013

Chung, Y.C., C. Huang and C.P. Tseng, 1996. Reduction of $\mathrm{H}_{2} \mathrm{~S} / \mathrm{NH}_{3}$ production from pig feces by controlling environmental conditions. J. Environ. Sci. Health, 31: 139-155. DOI: 10.1080/10934529609376348

Chung, Y.C., Y.Y. Lin and C.P. Tseng. 2005. Removal of high concentration of $\mathrm{NH}_{3}$ and coexistent $\mathrm{H}_{2} \mathrm{~S}$ by biological activated carbon (BAC) biotrickling filter. Bioresour. Technol., 96: 1812-1820. DOI: 10.1016/j.biortech.2005.01.003 
Gaudin, F., Y. Andres and P.L. Cloirec, 2008. Packing material formulation for odorous emission biofiltration. Chemosphere, 70: 958-966. DOI: 10.1016/j.chemosphere.2007.08.014

Guo, J., W.S. Xu, Y.L. Chen and A.C. Lua, 2005. Adsorption of $\mathrm{NH}_{3}$ onto activated carbon prepared from palm shells impregnated with $\mathrm{H}_{2} \mathrm{SO}_{4}$. J. Colloid Interf. Sci., 281: 285-290. DOI: 10.1016/j.jcis.2004.08.101

Hong, J.H. and K.J. Park, 2005. Compost biofiltration of ammonia gas from bin composting. Bioresour. Technol., 96: 741-745. DOI: 10.1016/j.biortech.2004.10.008

Juutilainen, S.J., P.A. Simell and A.Q.I. Krause, 2006. Zirconia: Selective oxidation catalyst for removal of tar and ammonia from biomass gasification gas. Appl. Catal. B: Envioron., 62: 86-92. DOI: 10.1016/j.apcatb.2005.05.009

Kim, J.H., E.R. Rene and H.S. Park, 2007. Performance of an immobilized cell biofilter for ammonia removal from contaminated air stream. Chemmosphere, 68: 274-280. DOI: 10.1016/j.chemosphere.2006.12.100

Kim, N.J., M. Hirai and M. Shoda. 2000. Comparison of organic and inorganic packing materials in the removal of ammonia gas in biofilters. J. Hazard. Mater., 72: 77-90. DOI: 10.1016/S03043894(99)00160-0

Ndegwa, P.M., A.N. Hristov, J. Arogo and R.E. Sheffield. 2008. A review of ammonia emission mitigation techniques for concentrated animal feeding operations. Biosystems Engineering, 100: 453-469. 10.1016/j.biosystemseng.2008.05.010

Pagans, E., X. Font and A. Sanchez. 2005. Biofiltration for ammonia removal from composting exhaust gases. Chem. Eng. J., 113: 105-110. DOI: 10.1016/j.biosystemseng.2007.03.035
Pagans, E., X. Font and A. Sanchez. 2007. Coupling composting and biofiltration for ammonia and volatile organic compound removal. Biosyst. Eng., 97: 491-500. DOI: 10.1016/j.cej.2005.03.004

Rodrigues, C.C., D.Jr. Moraes, S.W. Nobrega and M.G. Barboza. 2007. Ammonia adsorption in a fixed bed of activated carbon. Bioresour. Technol., 98: 886891. DOI: 10.1016/j.biortech.2006.03.024

Smet, E., H.V. Langenhove and K. Maes, 2000. Abatement of high concentrated ammonia loaded waste gases in compost biofilters. Water Air Soil Pollut., 119 : 177-190. DOI: 10.1023/A:1055186327201

Taghipour, H., M.R. Shahmansoury, B. Bina and H. Movahdian, 2008. Operational parameters in biofiltration of ammonia-contaminated air streams using compost-pieces of hard plastics filter media. Chem. Eng. J., 137: 198-204. DOI: 10.1016/j.cej.2007.04.015

Terasaka, K., J. Oka and H. Tsuge, 2002. Ammonia absorption from a bubble expanding at a submerged orifice into water. Chem. Eng. Sci., 57: 3757-3765. DOI: 10.1016/S0009-2509(02)00308-1

Wang, W., N. Padban, Z. Ye, A. Anderesson and I. Bjerle, 1999. Kinetics of ammonia decomposition in hot gas cleaning. Ind. Eng. Chem. Res., 38: 4175-4182. DOI: 10.1021/ie990337d

Wani, A.H., R.M.R. Branion and A.K. Lau, 1997. Biofiltration: A promising and cost-effective control technology for odors, VOCs and air toxics. J. Environ. Sci. Health, 32: 2027-2055. DOI: $10.1080 / 10934529376664$ 